See discussions, stats, and author profiles for this publication at:

http://www.researchgate.net/publication/226901055

\title{
DDT in Biota of Paranaguá Bay, Southern Brazil: Recent Input and Rapid Degradation
}

ARTICLE in WATER AIR AND SOIL POLLUTION · SEPTEMBER 2011

Impact Factor: 1.55 - DOI: 10.1007/s11270-011-0745-5

CITATIONS

9
READS

71

7 AUTHORS, INCLUDING:

\section{Daniela Brepohl}

Carl von Ossietzky Universität Oldenburg 7 PUBLICATIONS 111 CITATIONS

SEE PROFILE

Flavia Guebert

Federal University of Pernambuco 8 PUBLICATIONS 97 CITATIONS

SEE PROFILE
Juliane Rizzi

Universidade Federal do Paraná 3 PUBLICATIONS 9 CITATIONS

SEE PROFILE

Eunice C. Machado

Universidade Federal do Paraná

17 PUBLICATIONS 118 CITATIONS

SEE PROFILE 


\title{
DDT in Biota of Paranaguá Bay, Southern Brazil: Recent Input and Rapid Degradation
}

\author{
Gerd Liebezeit • Daniela Brepohl • Juliane Rizzi • \\ Flavia Guebert • Mats Krome • Eunice Machado • \\ Ursula Pijanowska
}

Received: 20 December 2010 / Accepted: 14 January 2011 /Published online: 1 February 2011

(C) Springer Science+Business Media B.V. 2011

\begin{abstract}
The presence of recent dichlorodiphenyltrichloroethane (DDT) inputs is established for Paranaguá Bay biota, i.e. bivalves, fish and one sponge. Values ranged from 6.9 to $156.2 \mathrm{ng} \Sigma \mathrm{DDT} / \mathrm{g}$ dry weight. Three fish species analysed showed 5 DDT values from 36.8 to $92.1 \mathrm{ng} / \mathrm{g}$ dry weight. The highest contents (up to $156.2 \mathrm{ng} \mathrm{\Sigma DDT} / \mathrm{g}$ dry weight) were found for mangrove oysters (Crassostrea rhizophorae) at locations affected by sewage discharge from Paranaguá City. Turtles as herbivores were not affected by this input with values of 0.7 and $2.2 \mathrm{ng} \Sigma \mathrm{DDT} / \mathrm{g}$ dry weight. The areal distribution of samples suggests that usage of DDT is widespread around the bay. Fresh DDT input is degraded to DDE and DDD within approximately 5 months.
\end{abstract}

Keywords DDT · Mussel · Oyster · Turtle · Fish · Brazil · Paranaguá Bay

G. Liebezeit $(\bowtie) \cdot$ D. Brepohl $\cdot$ M. Krome

Institute for Chemistry and Biology of the Marine

Environment, University of Oldenburg,

Schleusenstrasse 1,

26382 Wilhelmshaven, Germany

e-mail: gerd.liebezeit@uni-oldenburg.de

J. Rizzi $\cdot$ F. Guebert • E. Machado

Centro de Estudos do Mar,

Universidade Federal do Paraná,

CP 50 002, 83255-000 Pontal do Sul, Brazil

U. Pijanowska

Institute for Bird Research, An der Vogelwarte,

26386 Wilhelmshaven, Germany

\section{Introduction}

Chlorinated pesticides are common pollutants in coastal areas and estuaries (e.g. Tanabe et al. 2000; Klumpp et al. 2002; Wurl and Obbard 2005) being derived mainly from agricultural usage and insect control. As hydrophobic compounds, organochlorines tend to accumulate in the lipids of marine organisms. Marine mammals (e.g. Aguilar et al. 2002; Tanabe 2002) and mussels have been used extensively as sentinels for monitoring these compound classes (e.g. Tanabe et al. 2000).

The mangrove oyster Crassostrea rhizophorae, one of the bivalve species studied in the present communication, is a euryhaline species ranging in distribution from Southern Brazil until the Caribbean. This species represents an important food source in coastal areas from Brazil to Colombia (Mancera and Mendo 1996; Silva et al. 2001, 2006) and has been used in environmental toxicological studies also in Brazil (Silva et al. 2001; Alves et al. 2002; Zanette et al. 2006).

Connell et al. (1999) note that in the southern hemisphere, generally less contamination from organochlorines is found than in the northern hemisphere. The authors, however, also state that increased usage of chlorinated compounds in many tropical countries is observed with $\mathrm{HCBs}$, dichlorodiphenyltrichloroethane (DDT) and polychlorinated biphenyls (PCBs) occurrences apparently more localised in relation to the sources. Interestingly, brominated compounds 
analysed in livers of dolphins stranded along the southern Brazil coast had contents similar to those observed in northern hemisphere dolphins with methoxylated polybrominated diphenyl ethers being the highest reported for cetaceans so far (Dorneles et al. 2010). Similarly, perfluorooctane sulfonate levels in marine tucuxi dolphins from Guanabara Bay are among the highest detected to date in cetaceans (Dorneles et al. 2008).

With an overall consumption of about $106 \mathrm{kt}$ from 1947 to 1998 , Brazil is among the five countries worldwide with the highest DDT use in agriculture and for public health purposes ( $\mathrm{Li}$ and Macdonald 2005). A DDT ban had been installed in Brazil in 1971 for animal treatment and in 1986 for use in agriculture. A complete ban is in effect since 2009 . Until then, it was still in use for fighting epidemic insects (Paumgartten et al. 2000).

The estuarine complex of the Bay of Paranaguá (South Brazil, 25 $30^{\circ} \mathrm{S}, 48^{\circ} 30^{\prime} \mathrm{W}$ ) is a large subtropical system where pristine mangrove forests are still present, and fishery and aquaculture are important economic activities. In addition, harbour and related activities play a major role in the local economy.

A limited number of reports on environmental contaminants in the bay are available in the literature. Levels of both trace metals (Sá and da Costa Machado 2007) as well as polycyclic aromatic hydrocarbons (Fillmann et al. 2007) are generally below Brazilian action levels, the exception being arsenic. For this element, however, a natural source has been established.

According to IPARDES (1989) about $800 \mathrm{~kg}$ of pesticides per year were discharged into the bay largely from agricultural activities in the drainage area. Given the persistence of these compounds, it is not surprising that Valdez-Domingos et al. (2007) found histopathological lesions in C. rhizophorae gills although no direct relation to a specific contaminant was established.

There are indications that organotin (OT) compounds are present in the environment as Castro et al. (2007) found $>85 \%$ imposex in Stramonita haemastoma with the highest frequency close to Paranaguá harbour. This is supported by recent findings of Santos (2008) who reported high OT contents especially around the port of Paranaguá. Kolm et al. (2002) found the highest numbers of coliform bacteria near the city of Paranaguá related to the discharge of . untreated sewage.

\section{Material and Methods}

\subsection{Regional Setting}

Located on the southern coast of Brazil, the estuarine complex of Paranaguá Bay (CEP) extends from $25^{\circ}$ $16^{\prime}$ to $25^{\circ} 34^{\prime} \mathrm{S}$ and $48^{\circ} 17^{\prime}$ to $48^{\circ} 42^{\prime} \mathrm{W}$ (Fig. 1). It occupies a total area of $612 \mathrm{~km}^{2}$ and can be subdivided into two bays, one with east-west extension (56 km, Paranaguá/Antonina Bay), the other with north-south extension (30 km, Laranjeiras Bay) (Noernberg 2001).

The CEP receives drainage from approximately $70 \%$ of the coastal area of Paraná State (Mantovanelli 1999) with the E-W axis being predominantly influenced by continental runoff. Paranaguá Bay receives discharge of the rivers Cachoeira, Faisqueira, Nhundiaquara, Guaraguaçú, Itiberê and Anhaia, the latter two bordering the city of Paranaguá. The Itaqui Inlet in Laranjeiras Bay receives freshwater from the Guaraqueçaba, Serra Negra, Açungui, Tagaçaba and Morato rivers (Lana 1986). According to IPARDES (1989), the Cachoeira and Nhundiaquara rivers contribute $82 \%$ of the total discharge of continental water into the estuarine system. The flushing time of Paranaguá Bay varies between 3 and 10 days (Mantovanelli 1999). The turbidity maximum zone is located between Gererês Island and Paranaguá Harbour on the east-west axis (Noernberg 2001). The range of the astronomical tide is about $1.7 \mathrm{~m}$ in the mouth, but in the most interior areas it may reach $2.7 \mathrm{~m}$ (Camargo and Harari 2003).

The climate in the region is subtropical humid mesothermic with hot summer, according to the Köppen classification, with rainfall every month of the year, and a mean air temperature in the hottest month $>22^{\circ} \mathrm{C}$ (IPARDES 1990). Rainy periods dominate during spring and summer while drier weather prevails during autumn and winter.

CEP surface sediments are a mixture of terrestrial and biogenic material, becoming finer and less sorted towards the interior of the estuary (Bigarella et al. 1978; Angulo 1992). The grain size distribution is controlled by tidal currents in the eastern part and river flow in the western part. Soares et al. (1996) 


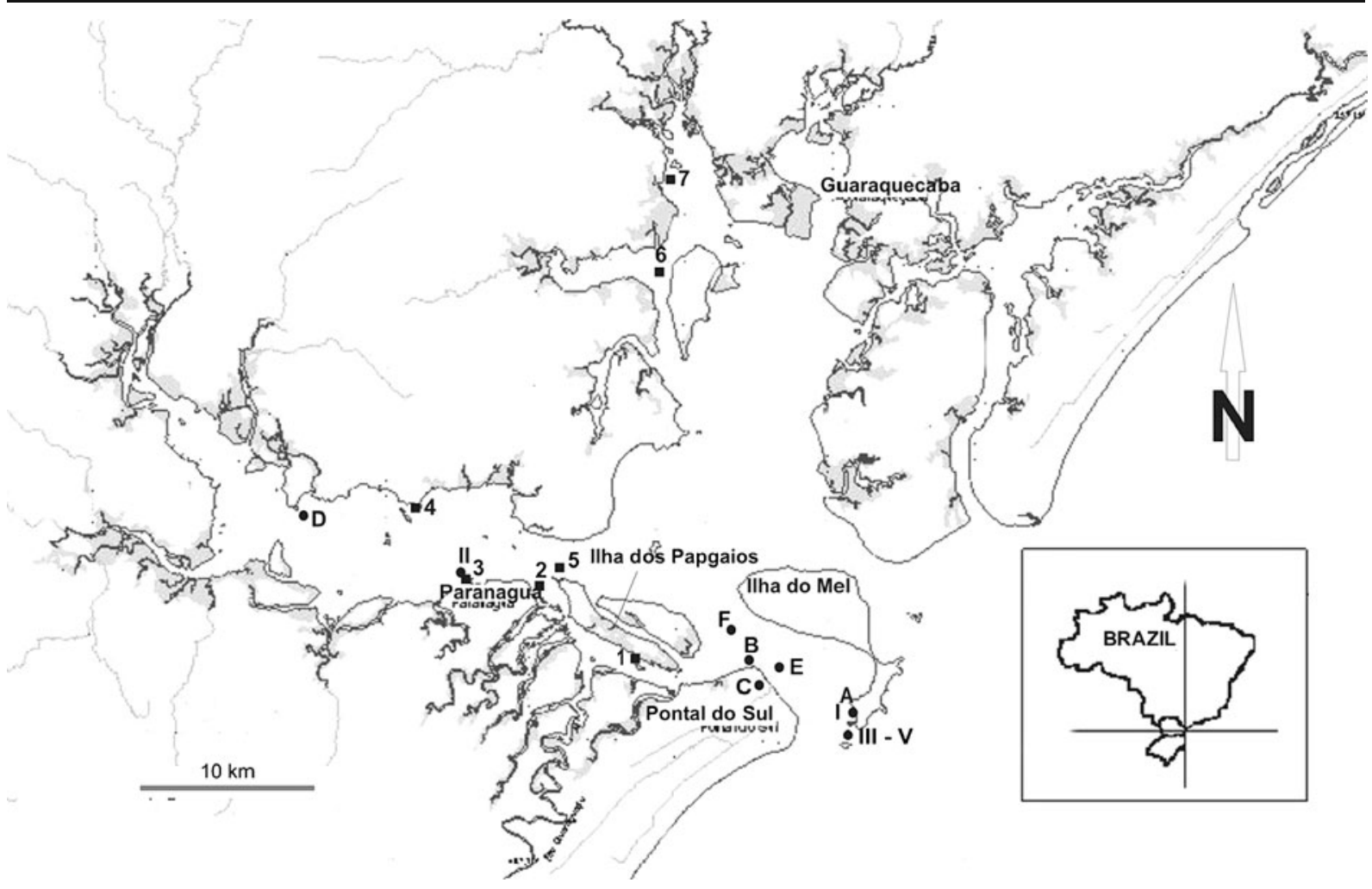

Fig. 1 Sampling stations in Paranaguá Bay. For details refer to Table 1

noted, however, an increase in median grain size in the latter area, presumably caused by deforestation and subsequent soil erosion.

\subsection{Sampling and Sample Workup}

Mytella guayensis, C. rhizophorae, Anomalocardia brasiliana and an unidentified sponge were collected in May 2006, August/September 2007 and February/ March 2008 at the locations given in Fig. 1. Two dead turtles (Chelonida mydas) were retrieved at the entrance of Paranaguá Bay in September 2007. Livers were dissected and lyophilised. In addition, three fish species were sampled in March 2008 as dead drifting specimens. Details are given in Table 1. The 2007 and 2008 samples were lyophilised in Brazil and analysed in Germany.

\subsection{Samples}

Five grammes of wet sample was macerated with $10 \mathrm{~g}$ of anhydrous sodium sulphate and after addition of
$200 \mu \mathrm{L}$ of a PCB-30 and PCB-103 mixture soxhlet extracted with $n$-hexane/dichloromethane 1:1 for $12 \mathrm{~h}$. The extract was rotary-evaporated to $10 \mathrm{~mL}$ and then cleaned by gel permeation chromatography (Bio-Beads ${ }^{\circledR}$ S-X3, Bio-Rad) using $n$-hexane/ dichloromethane 55:45. The first $80 \mathrm{~mL}$ containing lipids were discarded while the second fraction (120 mL) was volume-reduced to $1 \mathrm{~mL}$ and further fractionated into PCBs and pesticides over a Florisil column employing $n$-hexane and $n$-hexane/dichloromethane 1:4. The fraction containing DDT compounds was analysed with a Perkin Elmer Clarus 500 with electron capture detection using an Elite 5 column (60 m, $0.25 \mathrm{~mm}$ id, $0.25 \mu \mathrm{m}$ film thickness) under the following chromatographic conditions: injector temperature $280^{\circ} \mathrm{C}$, column temperature programme: $40-160^{\circ}$ $\mathrm{C}\left(20^{\circ} \mathrm{C} \mathrm{min}^{-1}\right) ; 160^{\circ} \mathrm{C}(5 \mathrm{~min}), 160-260^{\circ} \mathrm{C}\left(2^{\circ} \mathrm{C}\right.$ $\left.\min ^{-1}\right) ; 260^{\circ} \mathrm{C}(15 \mathrm{~min})$. Helium was used as the carrier gas.

For comparison, fresh weight contents were converted to a dry weight basis assuming a water content of C. rhizophorae of $85 \%$ (Rizzi 2007). 
Table 1 Background information and results for all species sampled in Paranaguá Bay

\begin{tabular}{|c|c|c|c|c|c|c|c|c|c|}
\hline \multirow[t]{2}{*}{ Time } & \multirow[t]{2}{*}{ Species } & \multirow[t]{2}{*}{ Location } & \multirow{2}{*}{$\begin{array}{l}\text { Label } \\
\text { (Fig. 1) }\end{array}$} & \multirow{2}{*}{$\begin{array}{l}\text { Length } \\
(\mathrm{cm})\end{array}$} & \multirow[t]{2}{*}{ Number } & \multirow{2}{*}{$\begin{array}{l}\text { Percent } \\
\text { lipid }\end{array}$} & \multicolumn{2}{|c|}{$\Sigma \mathrm{DDT}$} & \multirow{2}{*}{$\begin{array}{l}\text { DDT/ } \\
\text { DDE }\end{array}$} \\
\hline & & & & & & & $\begin{array}{l}(\mathrm{ng} / \mathrm{g} \\
\mathrm{dw})\end{array}$ & $\begin{array}{l}(\mu \mathrm{g} / \\
\mathrm{g} \text { lipid) }\end{array}$ & \\
\hline \multirow[t]{7}{*}{ May 2006} & $\begin{array}{l}\text { Crassotrea rhizophorae } \\
\text { (Ostreidae) }\end{array}$ & Gererês & 1 & $5.0 \pm 0.9$ & 9 & 0.86 & 25.2 & 2.9 & 0.3 \\
\hline & C. rhizophorae & Ilha Rasa & 2 & $4.9 \pm 0.9$ & 13 & 2.14 & 49.7 & 2.3 & 0.0 \\
\hline & C. rhizophorae & Anhaia & 3 & $5.3 \pm 0.7$ & 10 & 1.61 & 156.2 & 9.7 & 0.5 \\
\hline & C. rhizophorae & Itiberê & 4 & $5.0 \pm 0.6$ & 12 & 1.90 & 6.9 & 0.4 & 0.1 \\
\hline & C. rhizophorae & Ilha da Cotinga & 5 & $5.8 \pm 0.6$ & 9 & 2.57 & 23.6 & 0.9 & a \\
\hline & C. rhizophorae & Itaqui & 6 & $5.4 \pm 0.6$ & 12 & 1.50 & 20.3 & 1.4 & $\mathrm{a}$ \\
\hline & C. rhizophorae & $\begin{array}{l}\text { Ilha dos } \\
\text { Papagaios }\end{array}$ & 7 & $4.4 \pm 0.6$ & 13 & 2.38 & 86.2 & 3.6 & 0.1 \\
\hline August/ & Unidentified sponge & Inner bay & A & - & 1 & 0.60 & 17.9 & 3.0 & 2.2 \\
\hline \multirow{5}{*}{$\begin{array}{l}\text { September } \\
2007\end{array}$} & C. rhizophorae & Outer bay & B & $3.8 \pm 0.4$ & 12 & 1.78 & 21.0 & 1.2 & 3.0 \\
\hline & C. rhizophorae & Pontal do Sul & $\mathrm{C}$ & $5.4 \pm 0.9$ & 18 & 1.59 & 18.4 & 1.2 & 3.0 \\
\hline & Mytella guayensis (Mytilidae) & Ilha do Mel & $\mathrm{D}$ & $3.1 \pm 0.3$ & 20 & 2.50 & 40.9 & 1.6 & 2.9 \\
\hline & Chelonida mysida (Chelonidae) & Outer bay & $\mathrm{E}$ & & 1 & 5,30 & 2.2 & 0.0 & a \\
\hline & C. mysida & Outer bay & $\mathrm{F}$ & & 1 & 5.87 & 0.7 & 0.0 & a \\
\hline \multirow[t]{5}{*}{ March 2008} & M. guayensis & Ilha do Mel & I & $4.2 \pm 0.3$ & 14 & 2.04 & 38.1 & 1.9 & 0.2 \\
\hline & $\begin{array}{l}\text { Anomalocardia brasiliensis } \\
\text { (Veneridae) }\end{array}$ & Anhaia & II & $2.1 \pm 0.1$ & 12 & 1.77 & 78.8 & 4.4 & 0.2 \\
\hline & Cathorops sp. (Ariidae) & Bay & III & 12 & 1 & 1.95 & 92.1 & 4.7 & 0.0 \\
\hline & Stellifer brasiliensis (Sciaenidae) & Bay & IV & 5.5 & 1 & 1.70 & 53.5 & 3.1 & 0.3 \\
\hline & Paralonchurus sp. (Sciaenidae) & Bay & $\mathrm{V}$ & 9 & 1 & 1.17 & 36.8 & 3.1 & 0.1 \\
\hline
\end{tabular}

$d w$ dry weight

${ }^{\text {a No DDT }}$

\subsection{7 and 2008 Samples}

After lyophilisation dry tissue samples were weighed and anhydrous sodium sulphate and $100 \mu \mathrm{L}$ of $\mathrm{TBrB}$ solution added. This mixture was placed on top of a silica gel column and eluted with $120 \mathrm{~mL} n$-hexane/ dichloromethane retaining lipid material. The total extract was collected and rotary-evaporated to about $1 \mathrm{~mL}$ volume. The remaining volume was taken to dryness with a stream of nitrogen. After redissolution in $250 \mu \mathrm{L} i$-octane determination of organochlorine residues was by gas chromatography/mass spectrometry. A GC-MSD 5973 Series Agilent equipped with an HT5 SGE capillary column, with $25 \mathrm{~m} \times 0.22 \mathrm{~mm}$ internal diameter, film thickness of $0.1 \mu \mathrm{m}$ under the following chromatographic conditions: cold injection system (KAS, Gerstel); splitless, column temperature programme, $60-160^{\circ} \mathrm{C} \quad\left(40^{\circ} \mathrm{C} \min ^{-1}\right) ; 160-220^{\circ} \mathrm{C}$ $\left(2.5^{\circ} \mathrm{C} \min ^{-1}\right) ; 220-280^{\circ} \mathrm{C}\left(10^{\circ} \mathrm{C} \min ^{-1}\right) ; 280^{\circ} \mathrm{C}$ (5 min). Helium was used as carrier and makeup gas.

\section{Results and Discussion}

DDT and its degradation products dichlorodiphenyldichloroethylene (DDE) and dichlorodiphenyldichloroethane (DDD) were found in all samples from Paranaguá Bay (Fig. 2). The highest contents, both dry weight-based and total lipid normalised, were found for mangrove oysters and Anomalocardia brasilianensis from Anhaia (samples 3 and II) followed by mangrove oysters at Ilha dos Papagaios (\# 7) and the fish species Cathorops sp. (\# III). Samples D and I, i.e. M. guayensis from the Ilha do 
Fig. $2 \sum$ DDT in biota from Paranaguá Bay. Labelling according to Table 1

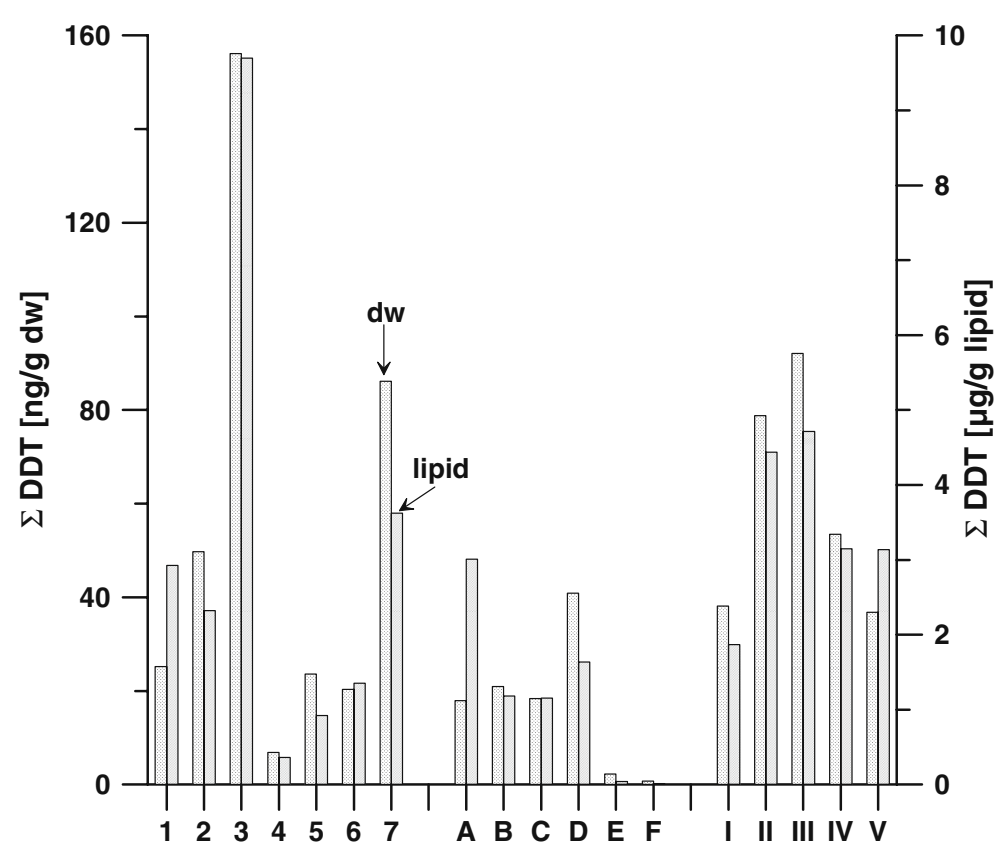

Mel, sampled at the same location, had comparable ¿DDT contents in September 2007 and March 2008. The turtle liver samples $\mathrm{E}$ and $\mathrm{F}$ had only extremely low $\Sigma$ DDT contents (Fig. 2).

The regional distribution pattern indicates that a significant input of DDT compounds occurs at the station Anhaia. This is an artificial channel discharging untreated sewage of Paranaguá City through a narrow mangrove belt into an area west of Paranaguá port. A. brasilianensis, a benthic mussel species, was sampled in front of the channel exit and was also found to be highly contaminated. It can thus be safely assumed that sewage or runoff from residential areas are the main sources of EDDT at this location. Similarly, station 7 at Ilha dos Papagaios is affected by discharge from the Itiberê River transporting runoff from the city of Paranaguá.

The relative composition is dominated in May 2006 and February/March 2008 by the degradation products DDE and DDD (Fig. 3). In August/September 2007 , on the other hand, DDT made up $60.7 \% \pm$ $0.08 \%$ in the filter feeding organisms while it was absent in the turtle samples. Correspondingly, mean DDT/DDE ratios were $0.28 / 0.15$ vs. 2.76 .

These findings suggest that there is a continuing de novo input of DDT into Paranaguá Bay. A recent pesticide input is also in line with findings of da Silva et al. (2008) who suggest continuing usage of hexachlorohexane and heptachlor for the Piracicaba River basin (São Paulo, Brazil) while DDT and its degradation product DDE could not be detected here.

Apparently, DDT in Paranaguá Bay is rapidly, i.e. within 5 months, degraded to primarily DDE as is evident from the marked decrease in DDT content of Mytella guayensis sampled on Ilha do Mel from early southern winter to summer (samples D and I in Fig. 3). Further degradation is, however, not evident as the absolute contents of $\mathrm{EDDT}$ in August/September 2008 were only 5\% lower than in February/March (Fig. 2).

These data indicate widespread usage of DDT in the land areas surrounding the bay. This is supported by hydrographic measurements and analyses of dissolved inorganic nutrients (N. Ladwig, personal communication 2008). Inorganic nutrients originate from river sources but are also introduced especially near Paranaguá City by sewage channels. DDT input via both these sources and rapid distribution by tidal currents may then lead to the observed occurrence of contaminants through the whole bay area.

Turtles that also feed in the bay are not exposed to high DDT levels in their seagrass diet as this, due to its low lipid content $(0.17 \%$ to $0.70 \%$ dry weight, Yamamuro and Chirapart 2005), will not accumulate 
Fig. 3 Relative composition of DDT compounds in biota samples from Paranaguá Bay. Labelling according to Table 1

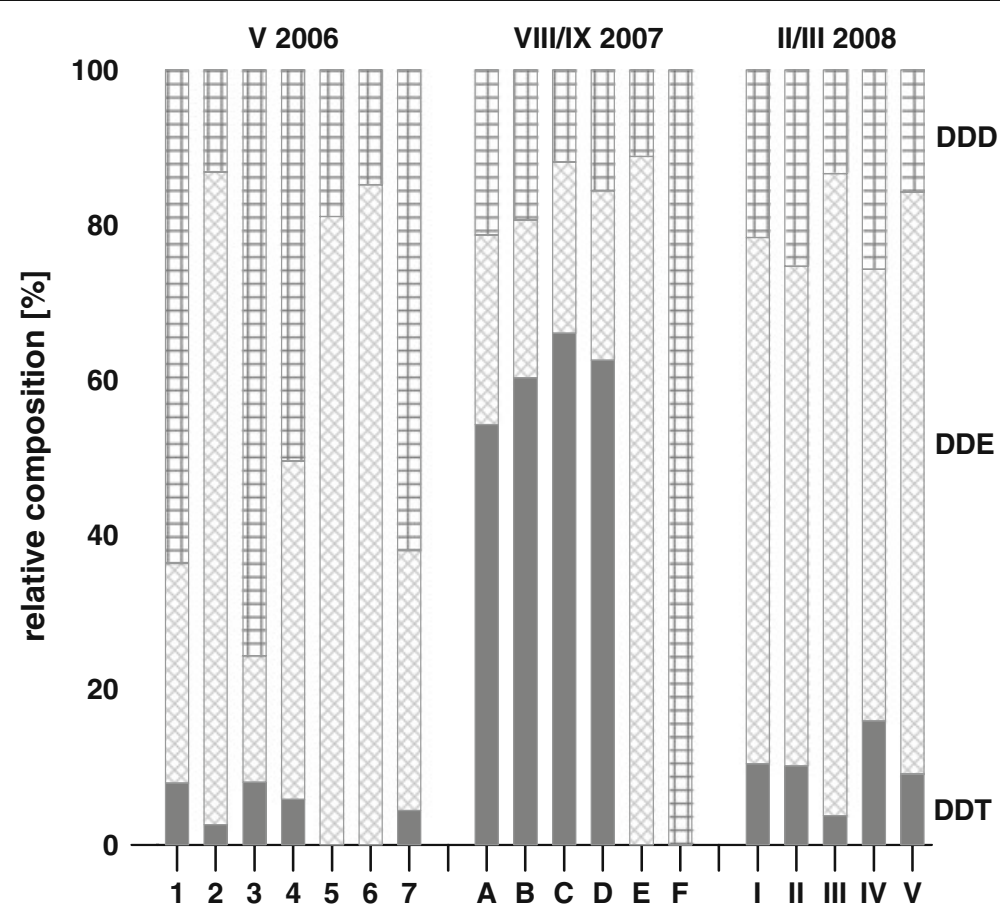

organochlorines to a significant extent. This is supported by findings for dugongs with a similar seagrass diet. Haynes et al. (2000) concluded that organochlorine contamination of dugongs from the Queensland cost, Australia, was low in comparison to concentrations recorded from marine mammal tissues collected elsewhere in the world.

Comparison with data from Todos os Santos Bay, northeast Brazil, indicates comparable or even higher maximum contents of DDT group compounds ( $\mathrm{Bra}$ chidontus exustus; Tavares et al. 1999). These authors point out that comparisons between different taxa have to be viewed with caution as different life histories may give rise to different bioaccumulation factors. Compared to other areas of the Brazilian coast (Table 2), EDDT values in biota of Paranaguá Bay are the highest reported so far.

In Guanabara Bay, Rio de Janeiro, de Brito et al. (2002) found DDT contents from 5.5 to $16.9 \mathrm{ng} / \mathrm{g}$ dry weight in the bivalve Perna perna with DDT/DDE ratios from 0.3 to 10.9 . There are seasonal effects as reported by de Brito et al. (2002) resulting in higher values during the dry season due to reduced runoff. Although not discussed by the authors, the high DDT/ DDE ratios also suggest recent input of DDT.

In Ribeirão Preto, State of São Paulo State, Brazil, Lopes et al. (1992) found DDT values of 0.19 to
$0.65 \mu \mathrm{g} / \mathrm{g}$ for Anodontites trapesialis with DDT/DDE ratios of 1 to 5.2. Seasonal effects here were related to agricultural activities, e.g. crop spraying.

In blue mussels (Mytilus edulis) and Pacific oysters (Crassostrea gigas) from the Wadden Sea, southern North Sea, the overall levels of the DDT group were $5.0 \pm 1.1 \mathrm{ng} / \mathrm{g}$ dry weight with DDT being present in only one sample out of a total of nine (Dörr and Liebezeit 2009). Here, insect control is not an issue in the adjacent terrestrial areas.

The three fish specimen analysed showed 5 DDT values from 36.8 to $92.1 \mathrm{ng} / \mathrm{g}$ dry weight. This compares with values of 21.8 to $101.5 \mathrm{ng} / \mathrm{g}$ dry weight given by Taniguchi (2001) for four species sampled along the coast of Rio de Janeiro state.

These data, together with the data for Paranaguá biota suggest that DDT application is still widespread along the Brazilian coasts. Accordingly, Kajiwara et al. (2004) found up to $150 \mu \mathrm{g} \Sigma \mathrm{DDT} / \mathrm{g}$ of lipid in the estuarine dolphin Sotalia guianensis indicating significant bioaccumulation of this compound class. On the other hand, Lailson-Brito et al. (2010) reported a maximum value of $23.4 \mu \mathrm{g} \Sigma \mathrm{DDT} / \mathrm{g}$ of lipid in blubber of $S$. guianensis collected amongst other locations in Paranaguá Bay.

Although there are effective monitoring programmes in Argentina, Brazil and Chile which generate a great 
deal of reliable data, these data are not always easily accessible (http://chm.pops.int/Portals/0/Repository/ COP2/UNEP-POPS-COP.2-INF-10.English.PDF). It is thus difficult to judge from the few published data the extent to which aquatic biota are actually exposed to DDT. Furthermore, one of the best tools against malaria remains indoor house spraying of DDT, according to WHO's Global Malaria Programme (WHO 2007). Thus, there is an apparent contradiction between the Brazilian DDT ban and the WHO recommendation.

\section{Conclusions}

The presence of recent inputs of DDT has been shown for Paranaguá Bay biota, i.e. fish, mussels, oysters and one sponge. Turtles as herbivores are not affected by this input. Seasonal usage of DDT is apparently still widespread around the bay despite its official ban since 1985. It can hence be expected that food chain accumulation may lead to negative effects in higher levels of the food web. From these findings, it can be concluded that further detailed work is needed for compounds used to combat insect plagues, especially in terms of food web accumulation.

\section{References}

Aguilar, A., Borrell, A., \& Reijnders, P. J. H. (2002). Geographical and temporal variation in levels of organochlorine contaminants in marine mammals. Marine Environmental Research, 53, 425-452.

Alves, S. R. C., Severino, P. C., Ibbotsom, D. P., Silva, A. Z. X., Lopes, F. R. A. S., Sa'enz, L. A., et al. (2002). Effects of furadan in the brown mussel Perna perna and in the mangrove oyster Crassostrea rhizophorae. Marine Environmental Research, 54, 241-245.

Angulo, R. J. (1992). Geologia da planície costeira do Estado do Paraná. Ph.D. Thesis (p. 334). Brazil: Universidade de São Paulo.

Bigarella, J. J., Becker, R. D., Matos, D. J. de, \& Werner, A. (1978). A Serra do Mar e a porção oriental do Estado do Paraná: Um problema de segurança ambiental de nacional. Governo de Estado do Paraná. Secretaria do Estado de Planejamento. Curitiba, Brazil, pp. 249.

Castro, I. B., de Bemvenuti, C. E., \& Fillmann, G. (2007). Preliminary appraisal of imposex in areas under the influence of southern Brazilian harbors. Journal of the Brazilian Society of Ecotoxicology, 2, 73-79.

Connell, D. W., Miller, G. J., Mortimer, M. R., Shaw, G. R., \& Anderson, S. M. (1999). Persistent lipophilic contaminants and other chemical residues in the Southern Hemisphere. Critical Reviews in Environmental Science and Technology, 29, 47-82.

Da Silva, D. M. L., de Camargo, P. B., Martinelli, L. A., Lanças, F. M., Pinto, J. S. S., \& Avelar, W. E. P. (2008). Organochlorine pesticides in Piracicaba river basin (São Paulo/Brazil): A survey of sediment, bivalve and fish. Quimia Nova, 31, 214-219.

De Brito, A. P. X., Brüning, I. M. R. D. A., \& Moreira, I. (2002). Chlorinated pesticides in mussels from Guanabara Bay, Rio de Janeiro, Brazil. Marine Pollution Bulletin, 44, 79-81.

De Camargo, R., \& Harari, J. (2003). Modeling the Paranaguá Estuarine Complex, Brazil: Tidal circulation and cotidal charts. Revista Brasileira de Oceanografia, 51, 23-31.

Dorneles, P. R., Lailson-Brito, J., Azevedo, A. F., Meyer, J., Vidal, L. G., Fragoso, A. B., et al. (2008). High accumulation of perfluorooctane sulfonate (PFOS) in marine tucuxi dolphins (Sotalia guianensis) from the Brazilian coast. Environmental Science \& Technology, 42, 5368-5373.

Dorneles, P. R., Lailson-Brito, J., Dirtu, A. C., Weijs, L., Azevedo, A. F., Torres, J. P. M., et al. (2010). Anthropogenic and naturally-produced organobrominated compounds in marine mammals from Brazil. Environment International, 36, 60-67.

Dörr, B., \& Liebezeit, G. (2009). Organochlorine compounds in blue mussels (Mytilus edulis) and Pacific oysters (Crassostrea gigas) from seven sites in the Lower Saxonian Wadden, Sea, southern North Sea. Bulletin of Environmental Contamination and Tocicology, 83, 874-879.

Fillmann, G., da Costa Machado, E., de Castro Martins, C., \& Sá, F. (2007). Poluentes orgânicos persistentes nos sedimentos dos canais de acceso aos portos de Paranaguá e Antonina (PR). In E. B. Boldrini, C. R. Soares \& E. Vedor de Paula (Eds.), Dragagens Portuárias no Brasil Licenciamento e Monitoramento Ambiental. Asso, pp. 264-275.

Haynes, D., Müller, J. \& Carter S. (2000). Pesticide and herbicide residues in sedimentsand seagrasses from the Great Barrier Reef World Heritage Area and Queensland Coast. Marine Pollution Bulletin, 41, 279-287.

IPARDES (1989). Zoneamento do litoral paranaense. Convênio: IPARDES e SEPL. Curitiba, Brazil, pp. 175. http://www. ipardes.gov.br/publicacoes/publicacoes_estudos_novo.php

IPARDES (1990). Macrozoneamento da APA de Guaraqueçaba. Convênio: Instituto Brasileiro do meio Abiente e dos Recursos Naturais Renovéis. Vol. 1: pp. 257, Vol. 2: pp. 11. http://www. ipardes.gov.br/publicacoes/publicacoes estudos novo.php

Kajiwara, N., Matsuoka, S., Iwata, H., Tanabe, S., Rosas, F. C. W., Fillmann, G. \& Readman, J. W. (2004). Contamination by persistent organochlorines in cetaceans incidentally caught along Brazilian coastal waters. Archives of Environmental Contamination and Toxicology, 46, 124-134.

Klumpp, D. W., Huasheng, H., Humphrey, C., Xinhong, W., \& Codi, S. (2002). Toxic contaminants and their biological effects in coastal waters of Xiamen. China. I. Organic pollutants in mussel and fish tissues. Marine Pollution Bulletin, 44, 752-760.

Kolm, H. E., Schoenenberger, M. F., da Rocha Piemonte, M., Souza, P. S. de A., Schüli, G. S., Mucciatto, M. B., et al. (2002). Spatial variation of bacteria in surface waters of Paranaguá and Antonina Bays, Paraná, Brazil. Brazilian Archive for Biology and Technology, 45, 27-34. 
Lailson-Brito, J., Dorneles, P. R., Azevedo-Silva, C. E., Azevedo, A. F., Vidal, L. G., Zanelatto, R. C., et al. (2010). High organochlorine accumulation in blubber of Guiana dolphin, Sotalia guianensis, from Brazilian coast and its use to establish geographical differences among populations. Environmental Pollution, 158, 1800-1808.

Lana, P. C. (1986). Macrofauna bêntica de fundos sublitorais não consolidados da Baía de Paranaguá (Paraná). Nerítica, 1, 79-89.

Li, Y. F., \& Macdonald, R. W. (2005). Sources and pathways of selected organochlorine pesticides to the Arctic and the effect of pathway divergence on $\mathrm{HCH}$ trends in biota: A review. The Science of the Total Environment, 342, 87106.

Lopes, J. L. C., Casanova, I. C., de Figueireido, M. C. G., Nather, F. C. \& Avelar W. E. P. (1992). Anodontites trapesialis: A biological monitor of organochlorin pesticides. Archives of Environmental Contamination and Toxicology, 23, 351-354.

Mancera, E., \& Mendo, J. (1996). Population dynamics of the oyster Crassostrea rhizophorae from the Cie'naga Grande de Santa Marta, Colombia. Fisheries Research, 26, 139148.

Mantovanelli, A. (1999). Caracterização da dinâmica hídrica e do material particulado em suspensão na Baía de Paranaguá e em sua bacia de drenagem. Mestrado em Geologia Ambiental Thesis, Universidade Federal do Paraná. Curitiba, Brazil, pp. 149.

Noernberg, M. A. (2001). Processos morfodinâmicos no Complexo Estuarino de Paranaguá-Paraná-Brasil: um estudo a partir de dados in situ e LANDSAT-TM. Ph.D. Thesis, Universidade Federal do Paraná, Curitiba, Brazil.

Paumgartten, F. J. R., Crus, C. M., Chahoud, I., Palavinskas, R., \& Mathar, W. (2000). PCDDs, PCDFs, PCBs, and other organochlorine compounds in human milk from Rio de Janeiro. Brazilian Environmental Research Section A, 83, 293-297.

Rizzi, J. (2007). Compostos organoclorados em ostras (Crassostrea rhizophorae) do Complexo Estuarino de PAranguá-PR. Monografia apresentada à disciplina de Estágio Supervisionado I, como requisito parcial à conclusão do Curso de Graduação em Oceanografia (p. 90). Universidade Federal do Paraná: Setor de Ciências da Terra.

Sá, F., da Costa Machado, E. (2007). Metais pesados e arsênio em sedimentos do canal de acceso aos portos de Estado de Paraná (PR). In E. B. Boldrini, C. R. Soares \& E. Vedor de Paula (Eds.), Dragagens Portuárias no Brasil Licenciamento e Monitoramento Ambiental, pp. 253-263.

Santos, D. M., Araújo, I. P., Machado, E. C., Carvalho-Filho, M. A. S., Fernandez, M. A., Marchi, M. R. R. \& Godoi A. F. L. (2009). Organotin compounds in the Paranaguá Estuarine Complex, Paraná, Brazil: Evaluation of biolog- ical effects, surface sediment, and suspended particulate matter. Marine Pollution Bulletin, 58, 1926-1931.

Silva, C. A. R., Rainbow, P. S., Smith, B. D., \& Santos, Z. L. (2001). Biomontoring of trace metal contamination in the Potengi estuary, Natal (Brazil), using the oyster Crassostrea rhizophorae, a local food source. Water Reseach, 35, 4072-4078.

Silva, C. A. R., Smith, B. D., \& Rainbow, P. S. (2006). Comparative biomonitors of coastal trace metal contamination in tropical South America (N. Brazil). Marine Environmental Research, 61, 439-455.

Soares, C. R., Lessa, G. C., Neto, A. G., Riesemberg, C. E. \& Silva, C. B. (1996). Caracterização da distribuição dos sedimentos de fundo das baías de Paranaguá e Antonina, Estado do Paraná: Anais XXXIX Congresso Brasileiro de Geologia, vol. 3, 390-393.

Tanabe, S. (2002). Contamination and toxic effects of persistent endocrine disrupters in marine mammals and birds. Marine Pollution Bulletin, 45, 69-77.

Tanabe, S., Prudente, M. S., Kann-atireklap, S., \& Subramanian, A. (2000). Mussel watch: Marine pollution monitoring of butyltins and organochlorines in coastal waters of Thailand, Philippines and India. Ocean and Coastal Management, 43, 819-839.

Taniguchi, S. (2001). Avaliação da contaminação por hidrocarbonetos e organoclorados em diferentes compartimentos do ambiente marinho do Estado do Rio de Janeiro. Ph.D: Thesis São Paulo University, pp. 160.

Tavares, T. M., Beretta, M., \& Costa, M. C. (1999). Ratio of DDT/DDE in the All Saints Bay, Brazil and its use in environmental management. Chemosphere, 38, 14451452.

Valdez-Domingos, F. X., Azevedo, M., Silva, M. D., Randi, M. A. F., Freire, C. A. \& Assis H. C. S.d., Ribeiro C. A. O. (2007). Multibiomarker assessment of three Brazilian estuaries using oysters as bioindicators. Environmental Research, 105, 350-363.

WHO (2007). Global Malaria Programme - The use of DDT in malaria vector control - WHO position statement, pp. 9. URL: http://apps.who.int/malaria/docs/IRS/DDT/DDTposition.pdf, visited 01 Oct 2009.

Wurl, O., \& Obbard, J. P. (2005). Organochlorine pesticides, polychlorinated biphenyls and polybrominated diphenyl ethers in Singapore's coastal marine sediments. Chemosphere, 58, 925-933.

Yamamuro, M., \& Chirapart, A. (2005). Quality of the seagrass Halophila ovalis on a Thai intertidal flat as food for the dugong. Journal of Oceanography, 61, 183-186.

Zanette, J., Monserrat, J. M., \& Bianchini, A. (2006). Biochemical biomarkers in gills of mangrove oyster Crassostrea rhizophorae from three Brazilian estuaries. Comparative Biochemistry and Physiology, 143C, 187-195. 